\title{
Retraction
}

\section{Retracted: Oral Haemangioma}

\section{Case Reports in Medicine}

Received 27 August 2014; Accepted 27 August 2014; Published 3 September 2014

Copyright (C) 2014 Case Reports in Medicine. This is an open access article distributed under the Creative Commons Attribution License, which permits unrestricted use, distribution, and reproduction in any medium, provided the original work is properly cited.

The article titled "Oral haemangioma" [1], published in Case Reports in Medicine, has been retracted as it is found to contain a substantial amount of material from the paper "Capillary hemangioma of palatal mucosa," Bharti Vipin, Singh Jagmohan, Journal of Indian Society of Periodontology, 2012; 16:475-8.

\section{References}

[1] J. S. Gill, S. Gill, A. Bhardwaj, and H. S. Grover, "Oral haemangioma," Case Reports in Medicine, vol. 2012, Article ID 347939, 4 pages, 2012. 